\title{
Chapter 9 \\ Industrial Policy, Industrial \\ Development, and Structural \\ Transformation in Asia and Africa
}

\author{
Yuki Higuchi and Go Shimada
}

\subsection{Introduction}

Industrial policy has long been a controversial issue among researchers and policymakers. Proponents of industrial policy, including early development economists like Hirschman (1958), Nurkse (1953), and Rosenstein-Rodan (1943), argue that big push-type policy to promote industrial development is central to economic development. Opponents argue that such interventionist policy will distort markets, and have a deleterious effect on economic growth (e.g., Baldwin 1969; Krueger and Tuncer 1982; Lal 1983). According to Newman et al. (2016, Chap. 2), the international trend of industrial policy can be divided into three phases. The first phase took place in the 1960s and 1970s, when the industrial policy was favorably accepted in the postindependence countries. In this period, import substitution industrialization (ISI) policies were adopted to promote certain domestic industries by means of tariffs and subsidies in many African countries under socialist regimes, such as, Ghana, Tanzania, and Zimbabwe. The ISI policies, however, failed to promote industrial development because these policies lacked linkages with markets and ignored the comparative advantage of the economy.

\footnotetext{
${ }^{1}$ The failure of African industrial policy in the 1960s and 1970s is similar to the experience of postindependence India, briefly discussed by Nomura (2018) in this volume. In both post-independence India and Africa, the government did not support labor-intensive industries, in which the country had comparative advantage.
}

Y. Higuchi (凶)

Graduate School of Economics, Nagoya City University, Nagoya, Japan

e-mail: higuchi@econ.nagoya-cu.ac.jp

G. Shimada

Meiji University, Tokyo, Japan

e-mail: go_shimada@meiji.ac.jp

K. Otsuka and K. Sugihara (eds.), Paths to the Emerging State in Asia and Africa,

Emerging-Economy State and International Policy Studies,

https://doi.org/10.1007/978-981-13-3131-2_9 
The second phase took place in the 1980s and the 1990s, when the Washington Consensus became an international norm, and structural adjustment programs (SAP) were adopted by the Bretton Woods Institutions, including the World Bank and the International Monetary Fund (IMF). ${ }^{2}$ In this second phase, the failure of ISI policies provoked harsh backlash against governmental intervention in industries, and the SAP program was favorably accepted, partially because of the widespread worldwide support for neoliberal regimes. The proponents of SAP policies emphasized the risk of government failure and political capture.

The third phase began in the 2000s when industrial policies were reconsidered as an important policy tool for economic development, as the rise of emerging economies like China, India, Brazil, and South Korea was observed. In this phase, the importance of narrowly defined industrial policy, in the form of previously failed ISI policies, has been muted, but the importance of policy to promote industrialization in general and to reform investment climate has been recognized. Although there is no universally accepted definition of industrial policy, the scope of industrial policy has expanded to include the selection and promotion of an industry in which a country has comparative advantage (e.g., Hausmann et al. 2005; Lin 2012) and even broader measures to correct market failures, including information asymmetry, externality, and coordination failure. The latter includes infrastructure development, job training, and research and development support to promote the industrial sector as a whole, not just specific industries (Harrison and Rodríguez-Clare 2010; Stiglitz et al. 2013). In this chapter, we do not formally define industrial policy, but we discuss the general importance of industrial policy and its potential in Africa.

The renewed attention to industrial policy in recent years has been called "the return of industrial policy" by Rodrik (2010), and a series of influential books have been published by Noman and Stiglitz $(2015,2016)$. The reasons behind the rising interest in industrial policy include the general recognition of the importance of job creation in the developing world, particularly after the Arab Spring, when unemployed educated youths started an economically motivated riot that ignited a political movement (World Bank 2012). In addition, a recent sign of successful industrialization in Ethiopia and Rwanda illustrated that industrial policy can promote structural transformation from the agricultural to the non-agricultural sector in Africa (Oqubay 2015; Noman and Stiglitz 2015; Dinh et al. 2012).

Furthermore, the importance of industrial policy in the history of the U.S. and Europe was rediscovered in recent studies (e.g., Chang 2007; Reinert 2007), and nascent literature empirically investigates the effect of industrial policies (Aghion et al. 2017; Criscuolo et al. 2012). Admitting that the literature is still emerging and not yet conclusive, Nunn and Trefler (2010) run a cross-country growth regression, and find that subsidies targeted to skill-intensive sectors promote economic growth, suggesting the ubiquitous role of industrial policy both in developed and developing countries. Lane (2017) attempts to establish causal impacts on industrial policy by

\footnotetext{
${ }^{2}$ The only international donor against the SAP was Japan. In 1993, the Overseas Economic Cooperation Fund (OECF, now JICA) published a paper in favor of industrial policy (OECF 1993). It caused controversy between the OECF and the World Bank (Mosley et al. 1995; Wade 1996).
} 
examining the case of Korea's big-push industrial policy from the 1970s. Using newly digitized data, and exploiting the unexpected beginning and sector-choice of the policy, Lane (2017) finds that industries targeted by the policy had significantly higher growth rates even after the termination of the policy, which also had a positive spillover effect on downstream industries.

In this chapter, we first discuss how industrial policy can help industrial development and economic growth using a simple conceptual framework. Based on our framework, we illustrate that industrial policy contributes to economic growth by enhancing labor productivity and reallocating labor from low productivity to high productivity sectors. Second, we use macroeconomic data from Asian and subSaharan African countries to present a sharp contrast between the two economies. Asian economies successfully achieved economic growth, which was led by the industrial development, particularly in labor-intensive sectors, whereas African economies have long been stagnant since independence, which can be attributed to the failure of industrialization. We also conduct decomposition analysis to show that the degree of labor reallocation is particularly limited in Africa. Lastly, we argue that managerial capacity is missing in Africa, and introduce a feasible strategy that has potential to stimulate African economic growth.

\subsection{Conceptual Framework}

We denote $Y$ as the real GDP and $L$ as the population of a country so that $Y / L$ indicates the country's GDP per capita. ${ }^{3}$ Furthermore, we denote $Y_{k}$ as the real GDP in sector $k$, where $k=$ agriculture (agr), industry (ind), or service (ser), and $L_{k}$ as the employment in sector $k$. Now, we obtain the following equation:

$$
Y / L=\left(Y_{a g r}+Y_{i n d}+Y_{s e r}\right) / L=\Sigma\left(Y_{k} / L\right)=\Sigma\left\{\left(Y_{k} / L_{k}\right) *\left(L_{k} / L\right)\right\}
$$

In the last expression, $Y_{k} / L_{k}$ represents intra-industry labor productivity and $L_{k} / L$ represents sectoral share of labor. Assuming the standard production function where output is a function of labor and capital with a given level of technology, the intraindustry labor productivity is a function of capital per capita (that is, capital deepening) and technology.

In this framework, industrial policies can enhance the intra-industry labor productivity or reallocate labor from a low productivity to a high productivity sector. The intra-industry productivity will be enhanced by infrastructure investment, institutional reform, and technology borrowing. In the agricultural sector, the land endowment is fixed, and thus, an increase in agricultural share of labor $\left(L_{a g r} / L\right)$ reduces

\footnotetext{
${ }^{3}$ We assume that the whole population is employed, but the main discussion remains the same if we define GDP per capita as $Y / N$, where $N$ is the total population. Then, $Y / N$ is the product of $Y / L$ and $L / N$, where the latter term represents the employment share of population. Under our assumption, we hold $L / N$ constant at one because the availability of the employment share data is limited.
} 
agricultural labor productivity $\left(Y_{a g r} / L_{a g r}\right)$ because of diminishing marginal product of labor. Although agricultural productivity may be improved by irrigation, land reform, or the use of improved agricultural technology and inputs, the value-added of share of agriculture $\left(Y_{a g r} / L\right)$ does not dramatically increase because of these offsetting effects.

In contrast, an increase in industrial share of labor $\left(L_{\text {ind }} / L\right)$ does not necessarily reduce industrial labor productivity $\left(Y_{\text {ind }} / L_{\text {ind }}\right)$ because the industrial sector is not constrained by land endowment. In particular, development of labor-intensive industries will increase both industrial productivity and industrial share of labor, so that the value-added of share of industry $\left(Y_{\text {ind }} / L\right)$ will dramatically increase. In addition, holding the service sector constant, the increase in industrial share of labor reduces agricultural share of labor, which in turn, increases agricultural labor productivity by reallocating surplus labor from the agriculture to industrial sector.

Indeed, the importance of the labor reallocation, or it can be stated as structural transformation, has received increasing attention both by researchers (e.g., Diao et al. 2017; Herrendorf et al. 2014; Hsieh and Klenow 2009; McMillan et al. 2014) and policymakers. A leading example is the Nairobi Declaration adopted after the Sixth Tokyo International Conference on African Development (TICAD VI) in 2016, where the heads of 54 African countries assembled. One of the three pillars of the declaration for future African economic development is "promoting structural economic transformation through economic diversification and industrialization." Hence, Eq. (9.1) illustrates the role of industrial policy in productivity improvement and labor reallocation. ${ }^{5}$

The service sector has traditional sub-sectors, mostly consisting of non-tradable goods and services, and modern sub-sectors, including finance and ICT-based services (Jensen 2011). An improvement in productivity in the former sub-sector is limited because of fixed local demand for non-tradable goods and services, whereas the latter sub-sector has potential for productivity increase. The modern sector, however, employs a small number of educated and highly skilled workers, and thus, the labor absorption capacity is limited (Goswami et al. 2011). Although the service sector is not constrained by land endowment, it is difficult to increase both service share of labor $\left(L_{s e r} / L\right)$ and service productivity $\left(Y_{s e r} / L_{s e r}\right)$. Taken together, the development of the industrial sector, particularly the labor-intensive industrial sector, is the most important channel for economic growth, particularly for countries that have comparative advantage in labor-intensive industry with abundant unskilled labor.

The wage structure in Africa is characterized as dual, in which a small number of highly skilled and educated workers earn high wage, whereas the rest earn low (Hino and Ranis 2013). In addition, fertility rates are still high in African countries so that they can take advantage of the population bonus. Hence, Africa has comparative

\footnotetext{
${ }^{4}$ http://www.mofa.go.jp/af/af1/page3e_000543.html (retrieved on November 23, 2018).

${ }^{5}$ Estudillo et al. (2018) in this volume discuss the labor allocation from agriculture to non-agriculture (i.e., industry and service sectors taken together) in Asia and Africa. They argue that the development of the non-agricultural sector was a key component of Asian economic growth and poverty reduction, whereas the majority of Africans are still engaged in the agricultural sector, and the structural transformation was slow.
} 
advantage in its unskilled labor with low wage, even compared with Asian countries whose recent economic growth puts upward pressure on wage. Importantly, the educational system has been developed and many African countries started to adopt free primary or even free secondary education programs, and thus, their labor force, which is not highly educated, but educated enough to be employable in the industrial sector, is increasingly available at relatively low cost.

Lastly, using Eq. (9.1), we adopt a canonical shift-share decomposition, originally developed by Fabricant (1942) and applied by McMillan et al. (2014) and De Vries et al. (2015) among others, to decompose the economic growth. The growth rate of GDP per capita can be decomposed as follows:

$$
\begin{aligned}
\Delta(Y / L)= & \Sigma\left\{\Delta\left(Y_{k} / L_{k}\right) *\left(L_{k} / L\right)\right\}+\Sigma\left\{\left(Y_{k} / L_{k}\right) * \Delta\left(L_{k} / L\right)\right\} \\
& +\Sigma\left\{\Delta\left(Y_{k} / L_{k}\right) * \Delta\left(L_{k} / L\right)\right\}
\end{aligned}
$$

where the first term on the right-hand side represents the within-industry labor productivity growth, the second term represents the static labor reallocation, and the third term represents the dynamic labor allocation. We conduct decomposition analysis based on Eq. (9.2) to examine the importance of labor productivity growth in each sector and structural transformation in the histories of Asia and Africa.

\subsection{Empirical Analyses}

\subsubsection{Sectoral GDP Per Capita}

We use GDP per capita data from the Penn World Table (PWT) version 8.1 (Feenstra et al. 2015) and sectoral share data from the World Bank's World Development Indicators (WDI). Combining the two datasets, Fig. 9.1 shows changes in sectoral GDP per capita (in 2011, constant USD at purchasing power parity) in log scale. We include 17 major Asian countries for analyses in this chapter: Bangladesh, China, Hong Kong, Indonesia, India, Japan, Cambodia, South Korea, Laos, Sri Lanka, Malaysia, Nepal, Pakistan, Philippines, Singapore, Thailand, and Vietnam. However, the sectoral share data for 1970 (and other years) is not available for Hong Kong, Cambodia, Laos, Singapore, and Vietnam, and thus, these five countries are excluded from Fig. 9.1 so that we can remove influences from the inclusion of sample countries, and focus on time-series changes of sectoral GDP per capita (see Appendix for data availability of our sample countries). In addition, the economic development of Japan, which started in the 1950s, was exceptional among the Asian countries, and thus, Japan's changes in sectoral GDP are separately presented in Panel B, whereas weighted averages of other emerging Asian countries are presented in Panel A.

Similar to Japan, South Africa was exceptional compared to other sub-Saharan African economies because, for instance, its GDP in 1970 accounted for a quarter of total GDP of all 45 sub-Saharan African countries. Therefore, weighted averages 
of sub-Saharan countries, excluding South Africa, are presented in Panel C, whereas Panel D presents the numbers for South Africa. In Panel C, we restrict our sample to 26 sub-Saharan African countries whose sectoral share data for 1970 is available.

Panel A: Asia

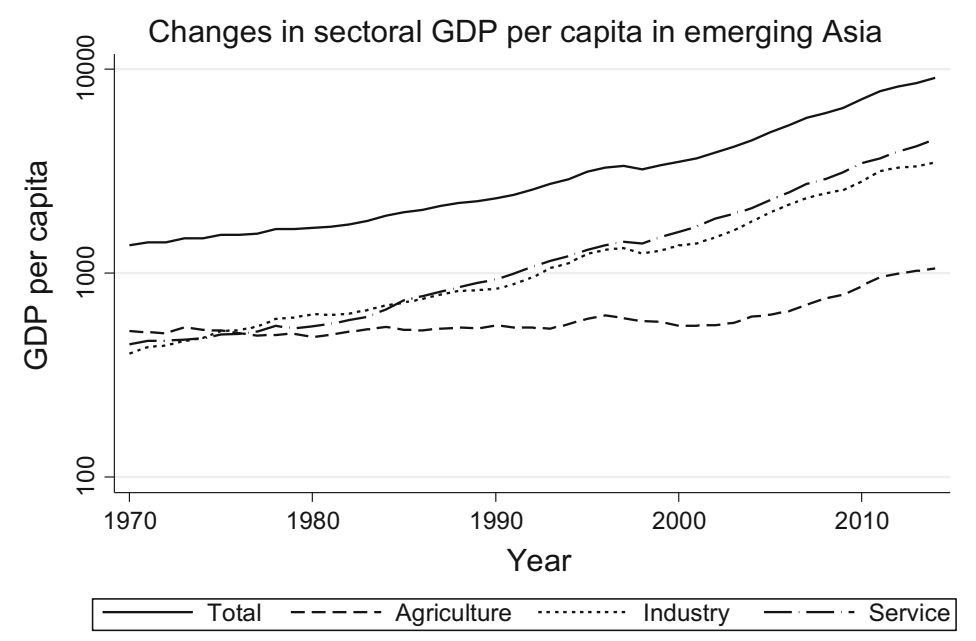

Panel B: Japan

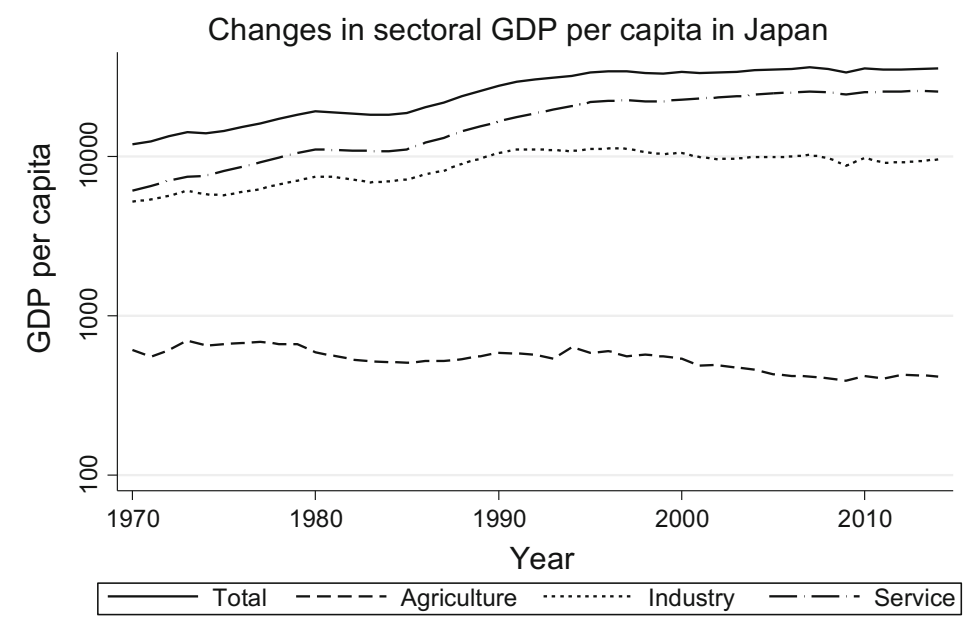

Fig. 9.1 Changes in sectoral GDP per capita in Asia and Sub-Saharan Africa. Source Penn World Table, World Development Indicators. Note GDP per capita is in USD (in PPP-adjusted 2011 constant price) and is presented in log scale. Panel A presents weighted averages (weight by population) of BGD, CHN, IDN, IND, KOR, LKA, MYS, NPL, PAK, PHL, and THA and Panel B presents numbers in JPN. Similarly, Panel C presents weighted averages of BDI, BEN, BFA, CAF, CIV, CMR, COG, GHA, GNB, KEN, LSO, MDG, MLI, MRT, MWI, NER, RWA, SDN, SLE, SWZ, TCD, TGO, UGA, ZMB, and ZWE and Panel D presents numbers in ZAF 
Panel C: Sub-Saharan Africa (excluding South Africa)

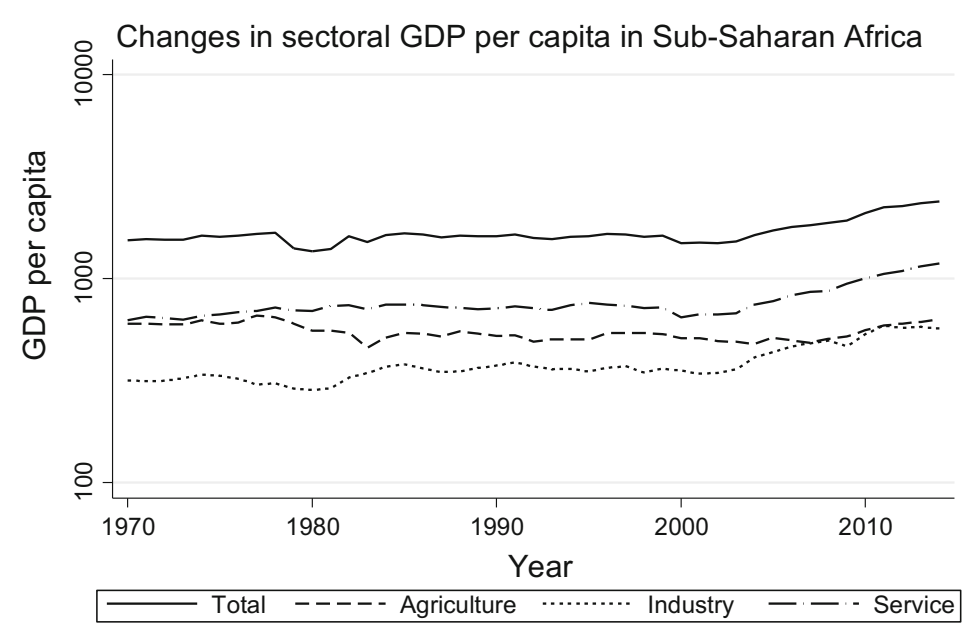

Panel D: South Africa

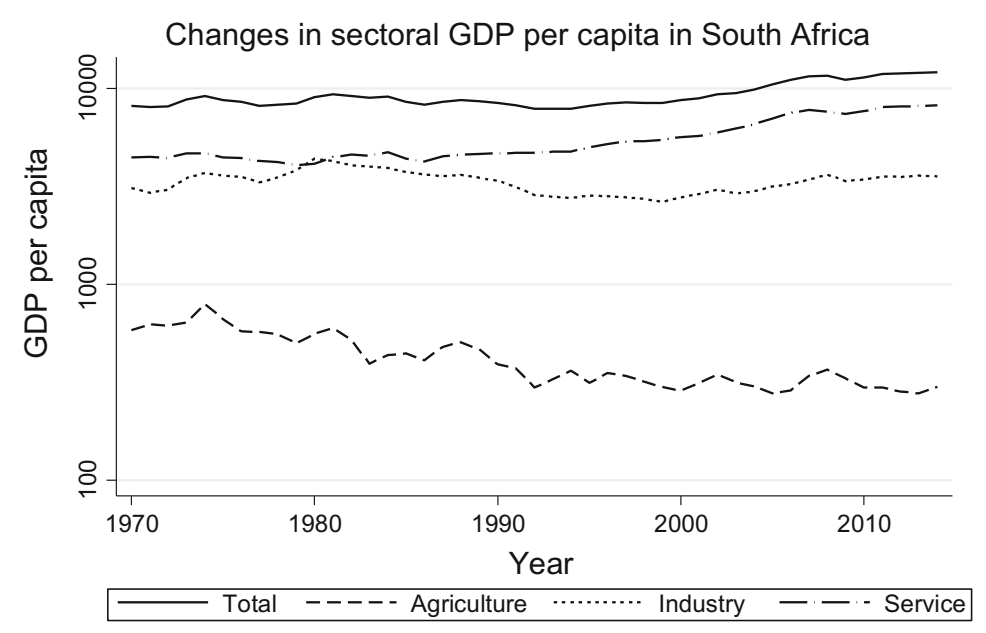

Fig. 9.1 (continued)

Although we limit our analyses to the 26 countries, the average level of GDP per capita is similar in Panel C and Fig. 9.2, which includes all the 45 sub-Saharan African countries for which GDP data is available, at around 2,000-3,000 USD, and thus, these 26 countries give a representative picture of the entire sub-Saharan African region.

Figure 9.1 corresponds to the second expression in Eq. (9.1), and presents a sharp contrast in the economic development of Asian and African economies. Panels A and C illustrate that the GDP per capita was at a similar level in 1970 in Asia and Africa. In 
1970, for instance, Korea's GDP per capita was 2,088 USD, which was comparable to that of Congo (2,281 USD) or that of Tanzania (1,750 USD), and was much lower than that of Ghana (2,843 USD). The two regions' economies have diverged, and the stagnation of African economies in the 1970s and 1980s, as discussed by Easterly and Levine (1997) among others, is evident in Panel C. The increase in Asia's GDP per capita seems to be a result of the increase in industrial GDP per capita and service GDP per capita, whereas the industrial GDP remained stagnant in Africa.

Using the same data as Fig. 9.1, Table 9.1 presents sectoral GDP per capita and the contribution of each sector in selected years. There are three major points to note. First, the agricultural GDP per capita is almost constant in the last four decades, particularly in Africa. As Gollin et al. (2014) find, the increase in agricultural productivity is cancelled out by the decrease in the labor share in agriculture, and thus, the agricultural GDP per capita did not increase despite the productivity improvement. This supports our argument in the previous section that economic growth cannot be achieved only by developing the agricultural sector.

Secondly, similar to the agricultural sector, the industrial GDP per capita has been stagnant at a low level over the past four decades in Africa. This suggests that neither the ISI policies adopted in the post-independent era of the 1960s and 1970s nor the SAP policies in the 1980s and 1990s helped industrialization in Africa. The SAP comprised market-oriented policies without governmental intervention, which can be considered an absence of industrial policy. The absence of industrial policy and subsequent failure in industrialization in Africa in the 1980s and 1990s is reminiscent of India's experiences as discussed by Nomura (2018) in this volume. Using data from Nigeria, Austin (2014) argues that the failure, as well as the absence, of industrial policies resulted in the failure of labor-intensive industrialization despite its potential for offering ample employment opportunities. ${ }^{6}$

In contrast, Asian economies experienced a rapid increase in industrial GDP per capita, which led to Asian economic growth. Otsuka et al. (2017a) discuss that industrial development played a critical role in Asian economies by increasing income without expanding inequality because labor-intensive industrial sectors created ample job opportunities. Similarly, Tanimoto (2018) and Kubo (2018) in this volume illustrate that labor-intensive industrialization took place in the early stage of economic development, which was followed by the development of capital-intensive industries in Japan and China, respectively. Stiglitz and Uy (1996) and Wade (1990) argue that such economic "miracle" of Asia, led by Japan and followed by Asian Tigers (Hong Kong, South Korea, Singapore, and Taiwan), was a consequence of industrial policies not in the form of ISI policies that ignored the comparative advantage but in the form of export-oriented policies that was friendly with markets and took advantage of the comparative advantage.

\footnotetext{
${ }^{6} \mathrm{We}$ admit that there are other factors, other than industrial policy, that hampered African industrialization. For instance, Frazer (2008) empirically finds that influx of used-clothing donation, which ended up being sold in Africa, had large negative impacts on apparel production. Discussing all possible factors that affected a specific industry is beyond the scope of this chapter, and we focus our discussion on industrial policy.
} 


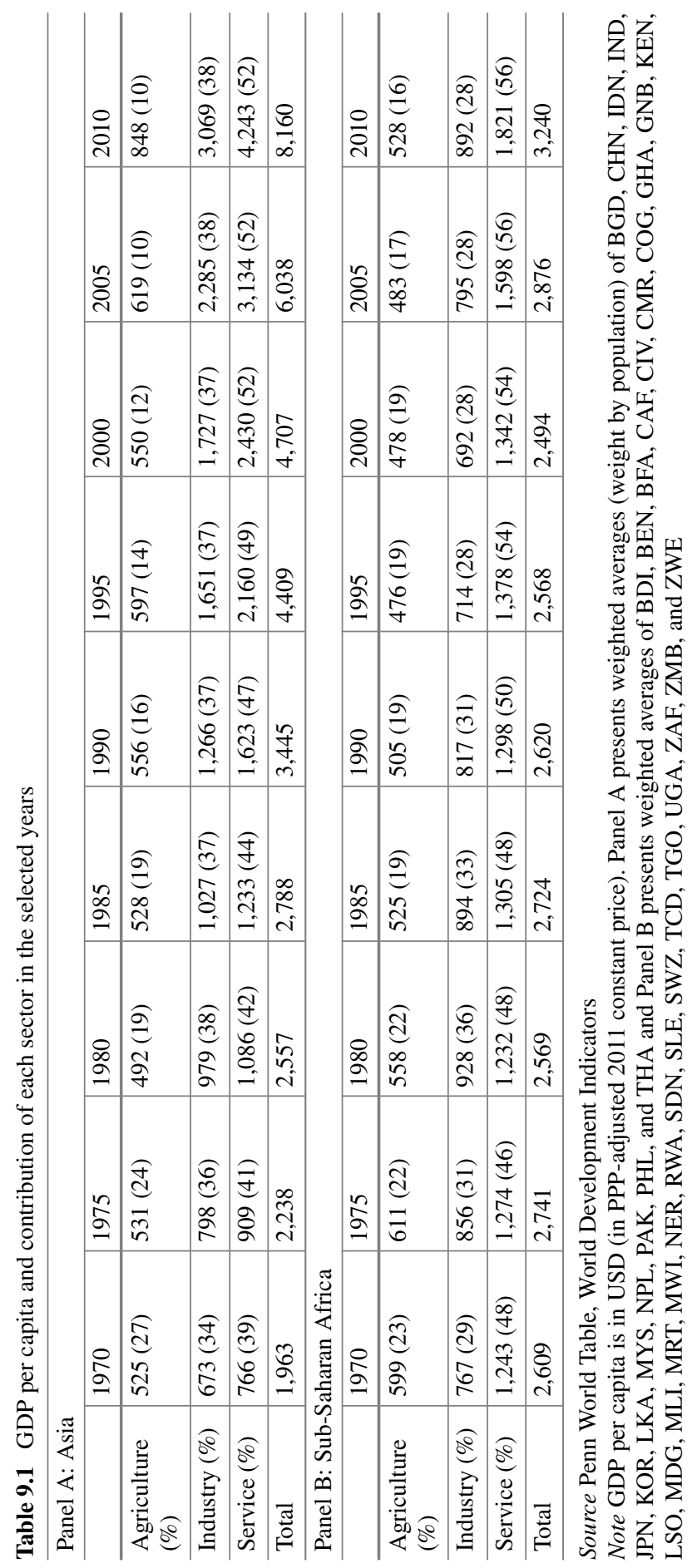


Third, the service GDP per capita increased both in Asia and Africa. In particular, the modest growth of GDP per capita after 2000 in Africa has been led by service sector growth. The GDP per capita increased from 2,494 USD in 2000 to 3,240 USD in 2010, and most of the increase can be attributed to the service sector growth. This phenomenon is known as premature deindustrialization (Haraguchi et al. 2017; Rodrik 2016) and premature shift to service industries (Page 2012). In Asia, Philippines and India are examples of economic growth driven by service sector growth, and a similar pattern is observed in Rwanda and Senegal. The labor absorption capacity, however, is limited in the service sector, particularly in modern service sectors like finance and ICT without backward and forward linkages in industries. These countries experience widening inequality within each country, and thus, this pattern of economic development seems to be unsustainable.

\subsubsection{Sectoral Employment}

Next, we show the sectoral share of employment in Table 9.2. As the data availability is severely limited, we replace a missing observation with the nearest observation of the same country within the four-year interval. ${ }^{7}$ We must note, however, that the number of observations is still small, particularly in the early period in our analyses. Our data shows that the agricultural share of employment has continuously decreased both in Asia and Africa, whereas the service sector share has continuously increased.

Admitting that sample countries do not overlap, Tables 9.1 and 9.2 suggest that industrial productivity has increased in Asia, but decreased in Africa, where the increase in employment share exceeds the increase in industrial GDP per capita. This stands in contrast to Duarte and Restuccia (2010) and Rodrik (2013), who find that manufacturing labor productivity unconditionally converges all over the world. Such exceptional absence of industrial productivity growth in Africa illustrates the failure of industrial development. At the same time, however, the low industrial productivity and global convergence suggests that there is potential room for increasing industrial labor productivity through industrial policies.

\subsubsection{Finer Sectoral Classification}

In order to analyze the contribution of specific industries to economic growth, we alternatively denote $k$ in Eq. (9.1) as narrowly defined industries, such as mining, manufacturing, trade, and finance, rather than the broadly defined industrial sector vis-à-vis agriculture and service sectors. We use data taken from the Groningen Growth and Development Centre (GGDC) 10-Sector Database (Timmer et al. 2014), which categorizes economic activities into ten groups, which are comparable across

\footnotetext{
${ }^{7}$ For instance, the employment share data of Burkina Faso is replaced with its 1994 value for years 1990 and 1995, but the observations are missing for 1985 and earlier (see columns toward right in Table 9.5 in Appendix).
} 
Table 9.2 Sectoral share of labor in selected years

\begin{tabular}{|c|c|c|c|c|c|c|c|c|c|}
\hline \multicolumn{10}{|l|}{ Panel A: Asia } \\
\hline & 1980 & 1985 & \multicolumn{2}{|c|}{1990} & \multicolumn{2}{|c|}{1995} & 2000 & 2005 & 2010 \\
\hline Agriculture (\%) & 38 & 38 & \multicolumn{2}{|c|}{41} & \multicolumn{2}{|l|}{44} & 39 & 32 & 33 \\
\hline Industry $(\%)$ & 24 & 23 & \multicolumn{2}{|l|}{22} & \multicolumn{2}{|l|}{19} & 19 & 21 & 21 \\
\hline Service $(\%)$ & 37 & 37 & \multicolumn{2}{|l|}{35} & \multicolumn{2}{|l|}{35} & 40 & 46 & 45 \\
\hline $\mathrm{N}$ & 11 & 12 & \multicolumn{2}{|l|}{14} & \multicolumn{2}{|l|}{17} & 16 & 16 & 17 \\
\hline \multicolumn{10}{|c|}{ Panel B: Sub-Saharan Africa } \\
\hline & 1985 & \multicolumn{2}{|l|}{1990} & \multicolumn{2}{|c|}{1995} & \multicolumn{2}{|c|}{2000} & 2005 & 2010 \\
\hline Agriculture (\%) & 84 & \multicolumn{2}{|l|}{75} & \multicolumn{2}{|c|}{68} & \multicolumn{2}{|c|}{62} & 57 & 53 \\
\hline Industry $(\%)$ & 5 & \multicolumn{2}{|l|}{6} & \multicolumn{2}{|c|}{7} & \multicolumn{2}{|l|}{9} & 11 & 13 \\
\hline Service $(\%)$ & 10 & \multicolumn{2}{|l|}{15} & \multicolumn{2}{|c|}{20} & 27 & & 29 & 34 \\
\hline $\mathrm{N}$ & 2 & 6 & & 7 & & 13 & & 17 & 14 \\
\hline Panel C: Sub-Sal & haran $A$ & a (includi & all cc & ountr & & & & & \\
\hline & 1980 & 1985 & 1990 & & 1995 & & 2000 & 2005 & 2010 \\
\hline Agriculture (\%) & 55 & 67 & 60 & & 56 & & 53 & 54 & 45 \\
\hline Industry (\%) & 11 & 8 & 10 & & 11 & & 12 & 11 & 14 \\
\hline Service $(\%)$ & 32 & 24 & 27 & & 30 & & 34 & 32 & 40 \\
\hline $\mathrm{N}$ & 3 & 6 & 16 & & 17 & & 22 & 28 & 26 \\
\hline
\end{tabular}

Source Penn World Table, World Development Indicators

Note Simple averages in Asia and Sub-Africa are presented. Asia includes BGD, CHN, HKG, IDN, IND, JPN, KHM, KOR, LKA, MYS, NPL, PAK, PHL, SGP, THA, and VNM and selected Africa includes BDI, BEN, BFA, CAF, CIV, CMR, COG, GHA, GNB, KEN, LSO, MDG, MLI, MRT, MWI, NER, RWA, SDN, SLE, SWZ, TCD, TGO, UGA, ZAF, ZMB, and ZWE

countries and over time. Although the GGDC data has advantages over comparable and finer classifications of industries, the data coverage is limited. The sample Asian countries include China, Hong Kong, Indonesia, India, Japan, South Korea, Malaysia, Philippines, Singapore, and Thailand (nine of the original 16 sample countries) and the sample African countries include Botswana, Ethiopia, Ghana, Kenya, Mauritius, Malawi, Nigeria, Senegal, Tanzania, South Africa, and Zambia (11 of the original 45 sample countries).

Table 9.3 shows the sectoral contribution to GDP per capita and employment. The agricultural share of GDP per capita has decreased, and the share of the service sector has increased, particularly the finance sector both in Asia and Africa. In the previous sub-sections, the industrial sector included both mining and manufacturing sectors. The share of mining sector is larger in Africa than in Asia, particularly because the African sample countries incudes Botswana and Nigeria, resource-rich countries with relatively high per capita GDP in Sub-Saharan Africa. The employment share of mining, however, is small because the sector is intensive in capital-use and the employment creation is limited. 
The manufacturing sector, which is represented by labor-intensive industries and absorbs large amounts of labor, presents clear contrast in the two regions. The manufacturing share of value added in Asia was already much higher than in Africa at $18.9 \%$ in 1970 , and further increased to $23.3 \%$ in 2010 so that almost a quarter of Asian value-added is from the manufacturing sector today whereas the share in Africa has been stagnant at around $10 \%$. Moreover, the value-added share of the manufacturing sector has increased more than the employment share in Asia, indicating that the labor productivity in the manufacturing sector has increased. Therefore, the manufacturing sector creates numerous high value-adding jobs, and contributes to Asian economic growth.

\subsubsection{Decomposition Analysis}

Table 9.4 shows the results of decomposition analyses based on Eq. (9.2). Row (A) corresponds to the first term on the right-hand side, and represents within-industry labor productivity growth. Both in Asia and Africa, this accounts for a large proportion of labor productivity growth. Row (B) represents static labor reallocation, whereas row $(\mathrm{C})$ represents dynamic labor allocation. In Africa, the latter is negative and large in magnitude. Africa is experiencing urbanization and expansion of urban slums, and the urban service sector, mostly in informal economy, absorbs labor from rural areas. The productivity of such sector, however, remains low. On the other hand, the reduction of surplus agricultural labor increases agricultural labor productivity. Therefore, the contribution of dynamic labor reallocation is negative because the labor shifts away from agriculture, whose productivity increases, to other sectors-mostly the service sector, where the productivity does not increase.

We combine rows (B) and (C) to examine the total effect of labor reallocation. In Asia, the contribution is positive. Between both 1990-2000 and 2000-2010, labor reallocation contributes to about $1 \%$ of annual productivity growth. However, the contribution of labor reallocation is negative in Africa. In other words, the structural transformation does not account for economic development. Although the labor shifts from agricultural sector to other sectors, the productivity is low in these sectors. 


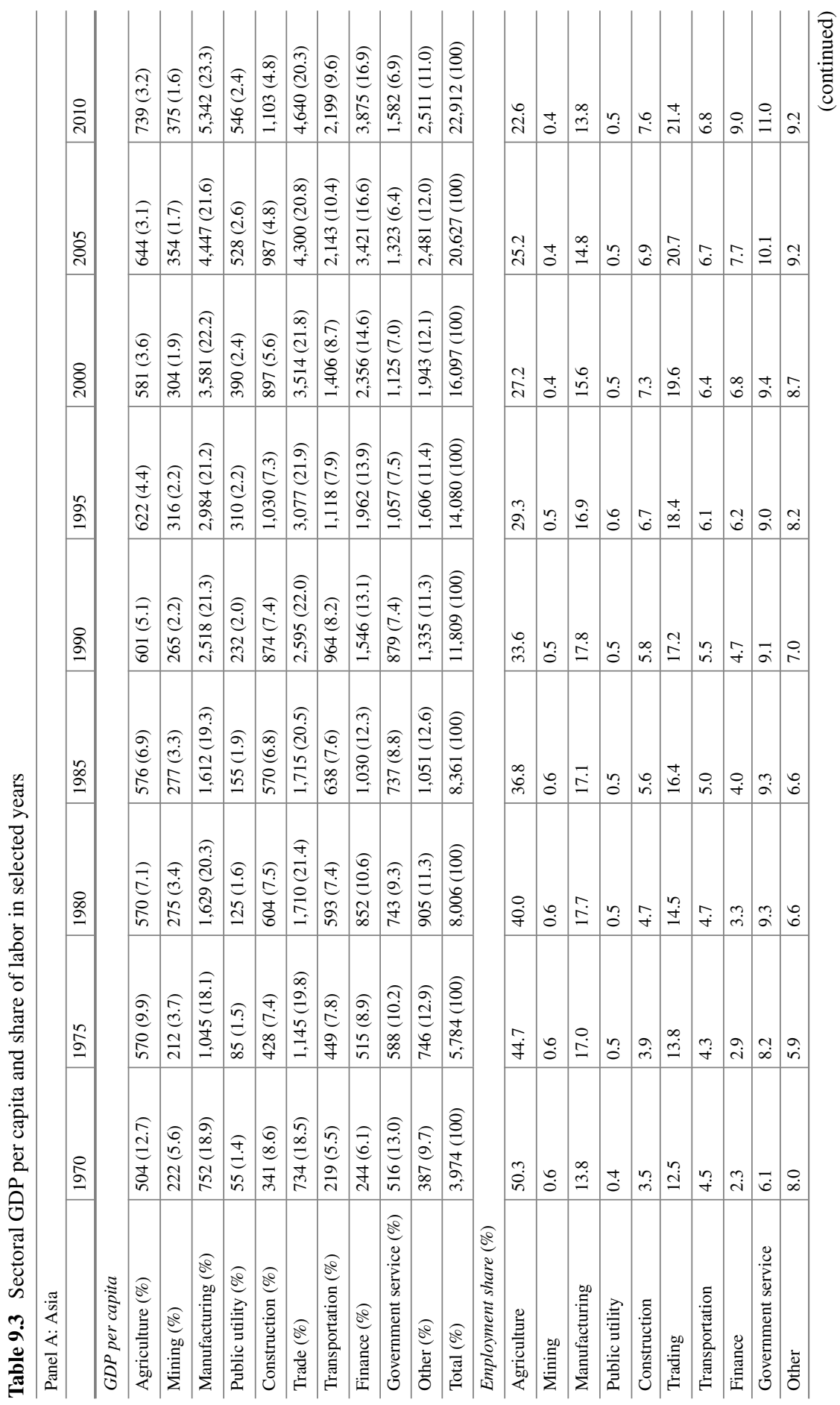




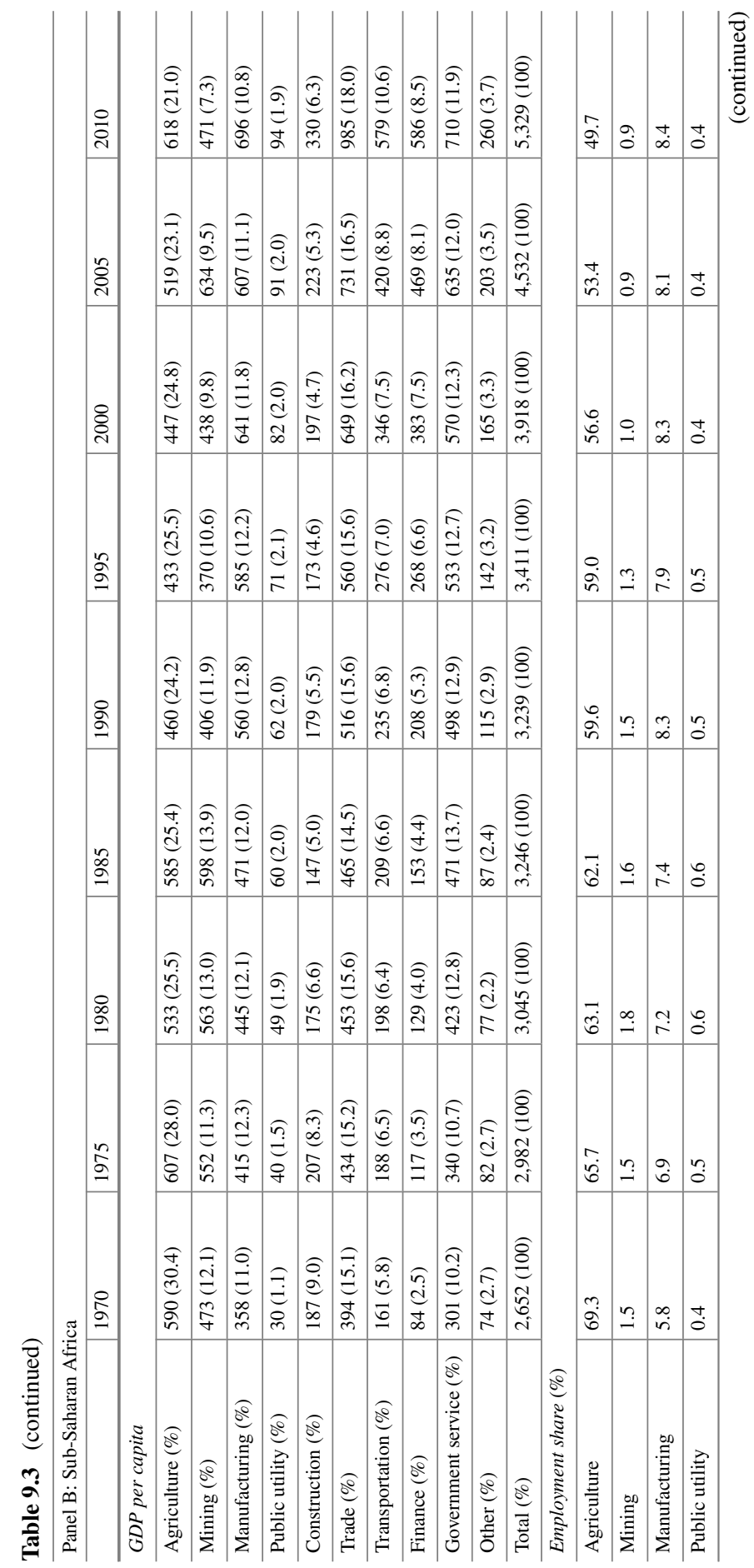


9 Industrial Policy, Industrial Development ...

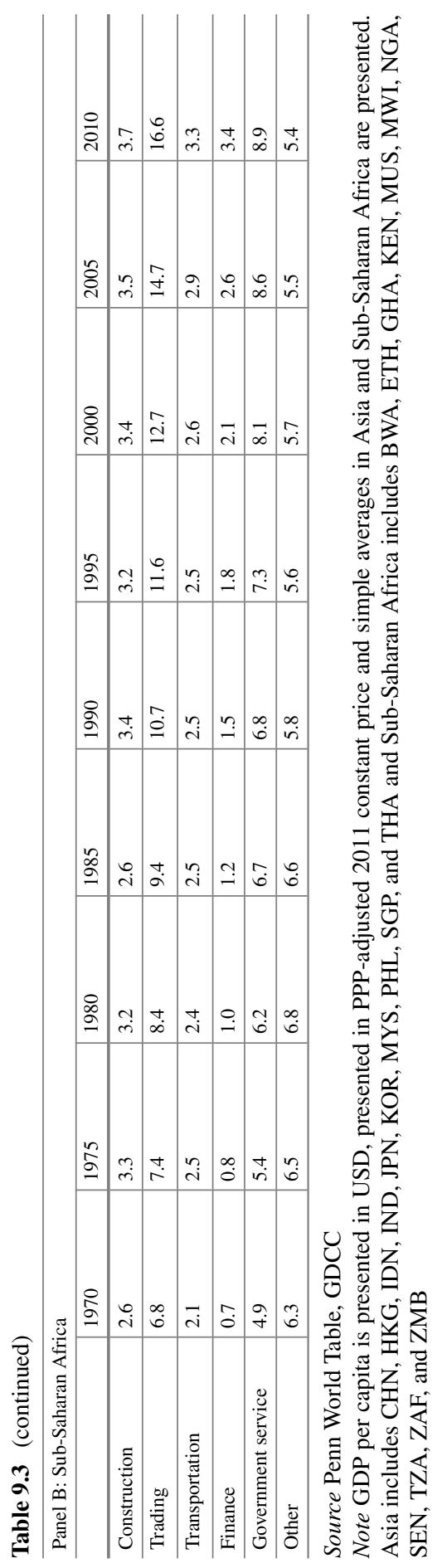




\subsection{What Is Missing?}

The comparison of macroeconomic data of Asia and Africa shows a sharp contrast between the two regions' economies. Admitting that there are various differences in the two regions, in terms of population (Asia with 4 billion and Africa with 1 billion) and land size (Asian countries spread over a vast area, and African countries, many of them landlocked, are concentrated in relatively small areas), Asia successfully achieved economic growth led by industrialization, and Africa's economies have long been stagnant. Although African economies have recently achieved modest growth because of the expansion of the service sector and improved agricultural productivity (mostly because of the declining share of agricultural employment), this is not a sustainable way of economic growth. The land endowment is limited, and subsequently, labor absorption capacity is limited in the agricultural sector, and the modern service sector also has limited capacity for labor absorption. If only the modern service sector grows and creates high-income jobs for a handful of educated and highly skilled workers, the problem of inequality will be a social concern. Therefore,

Table 9.4 Decomposition of GDP per capita growth

\begin{tabular}{|c|c|c|}
\hline \multicolumn{3}{|l|}{ Panel A: Asia (excluding Japan) } \\
\hline & $1990-2010$ & $2000-2010$ \\
\hline $\begin{array}{l}\text { Annual GDP per capita growth } \\
(\%)\end{array}$ & 4.0 & 5.2 \\
\hline $\begin{array}{l}\text { (A) Within sector labor } \\
\text { productivity growth }\end{array}$ & 3.1 & 4.3 \\
\hline (B) Static labor reallocation & 0.8 & 0.9 \\
\hline $\begin{array}{l}\text { (C) Dynamic labor } \\
\text { reallocation }\end{array}$ & 0.2 & -0.0 \\
\hline $\mathrm{N}$ & 12 & 16 \\
\hline \multicolumn{3}{|l|}{ Panel B: Sub-Saharan Africa } \\
\hline & $1990-2010$ & $2000-2010$ \\
\hline $\begin{array}{l}\text { Annual GDP per capita growth } \\
(\%)\end{array}$ & 1.5 & 3.0 \\
\hline $\begin{array}{l}\text { (A) Within sector labor } \\
\text { productivity growth }\end{array}$ & 1.7 & 3.8 \\
\hline (B) Static labor reallocation & 1.3 & 0.9 \\
\hline $\begin{array}{l}\text { (C) Dynamic labor } \\
\text { reallocation }\end{array}$ & -1.5 & -1.6 \\
\hline $\mathrm{N}$ & 9 & 16 \\
\hline
\end{tabular}

Source Authors' calculation using Penn World Table and WDI

Note Asia includes BGD, CHN, HKG, IDN, IND, JPN, KHM, KOR, LKA, MYS, NPL, PAK, PHL, SGP, THA, and VNM and Sub-Saharan Africa includes BDI, BEN, BFA, CAF, CIV, CMR, COG, GHA, GNB, KEN, LSO, MDG, MLI, MRT, MWI, NER, RWA, SDN, SLE, SWZ, TCD, TGO, UGA, ZAF, ZMB, and ZWE 
development of the labor-intensive sector is important for sustainable and equitable development.

Recent empirical studies find that firms' managerial capital is missing in the developing countries, particularly in Africa (e.g., Bloom et al. 2012). Although firms are the drivers of industrial development, firm owners and managers have limited capacity to manage their firms and workers, and consequently, their business is unstable and short-lived. A number of recent studies, however, find that such managerial capacity can be taught by training, consultation, or coaching (e.g., Higuchi et al. 2015; McKenzie and Woodruff 2014; Shimada and Sonobe 2017). Hence, the capacity building of firms is an important policy tool for promoting industrialization.

Otsuka et al. (2017b) further advance the discussion, and propose the traininginfrastructure-finance (TIF) strategy as a plausible set of policies for stimulating economic growth in Africa. ${ }^{8}$ Unlike failed industrial policies in the past that ignored the comparative advantage, the TIF strategy aims to upgrade the existing industries, rather than developing new industries. Sonobe and Otsuka (2011) find that there are numerous industrial clusters of labor-intensive industries, such as apparel, shoemaking, food processing, and metalworking, which were spontaneously formed in the developing world. These industries survive in markets because they take advantage of abundant labor, but their products are usually of low-quality because of the limited capacity of firms in developing countries, particularly in Africa. Therefore, the TIF strategy aims to support and upgrade these existing industries.

The essence of the TIF strategy is to provide training, infrastructure, and finance as a strategic sequence. The first of the sequence is to provide training to invest in human capital in general and managerial human capital of firm owners and managers in particular, and then, to invest in infrastructure, particularly the establishment of industrial parks or zones, and lastly, to provide financial support for competent entrepreneurs. ${ }^{9}$ This strategy begins with identifying potential entrepreneurs and nurturing their managerial capital, which eventually increases $L_{\text {ind }} / L$. Together with the investment in human capital, investment in infrastructure helps increase productivity, $Y_{\text {ind }} / L_{\text {ind }}$. The establishment of industrial parks, in particular, helps increase industrial productivity by taking advantage of agglomeration economies, such as knowledge spillover, input-output linkages, and skilled-labor market formation. This, in turn, further increases $L_{\text {ind }} / L$ by creating not only entrepreneurial jobs, but also hired employment. The financial support further helps to create hired employment and improve productivity by supporting promising enterprises.

\footnotetext{
${ }^{8}$ Similar industrial policies are recommended by Shimada et al. (2013) and Dinh et al. (2012), although the importance of sequence is not emphasized. Otsuka et al. (2017b) emphasizes the importance of sequence in providing training, infrastructure, and finance as a strategic set of policy instruments.

${ }^{9}$ Hashino and Otsuka (2016) find from the Japanese history that governmental support for industrial clusters was an effective policy to enhance productivity.
} 


\subsection{Conclusion}

This chapter compares the performance of Asian and African economies in the past half century. Starting with almost similar levels of GDP per capita at around 2,000 USD in 1970, the Asian economies experienced rapid economic growth and GDP per capita increased almost to 10,000 USD in 2015. On the other hand, the African economies had long been stagnant, and GDP per capita in 2015 was about 3,500 USD. We argue that Asia's economic success can, at least partially, be attributed to the industrial development, which increased the industrial productivity and the share of employment in the industrial sector.

Africa largely lacks industrial productivity growth and structural shift to the industrial sector. Now that Asian countries are losing comparative advantage in laborintensive industries because of the increasing wage rates, Africa has a chance for industrialization. In particular, China, which used to be the world's factory, is shifting away from labor-intensive industries. Hence, decent industrial policies, including the TIF strategy, are expected to stimulate African industrial development so that Africa can be a next production base of labor-intensive products.

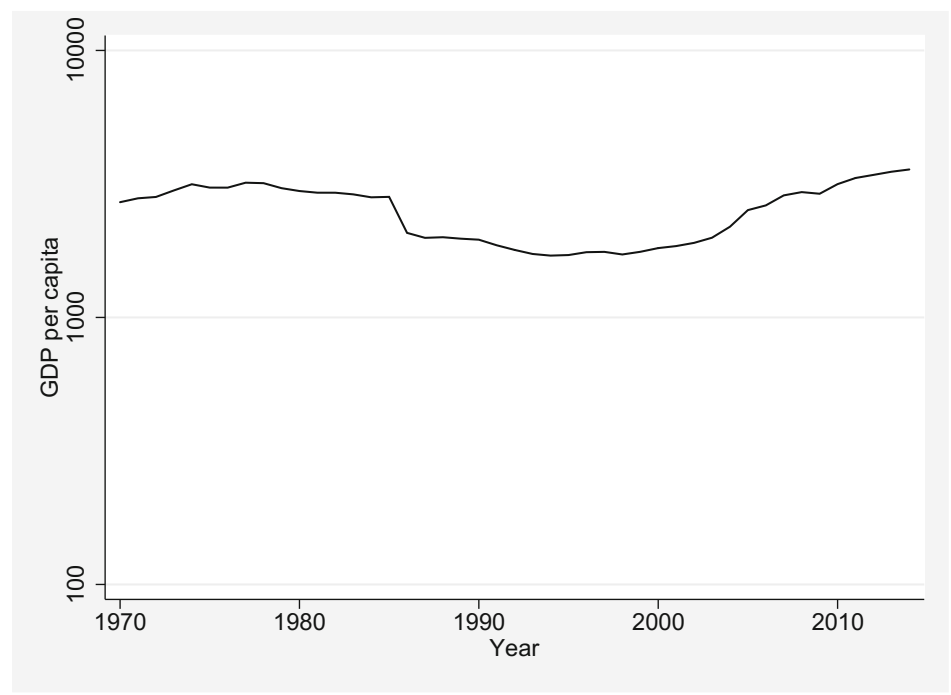

Fig. 9.2 Changes in GDP per capita in all Sub-Saharan African countries. Source Penn World Table, World Development Indicators. GDP per capita is in USD (in PPP-adjusted 2011 constant price) and is presented in log scale. All Sub-Saharan countries, whose GDP data is available are included 


\section{Appendix}

See Fig. 9.2 and Table 9.5.

Table 9.5 Data availability

\begin{tabular}{|c|c|c|c|c|}
\hline Code & Country & PWT & $\begin{array}{l}\text { Value added } \\
\text { share (WDI) }\end{array}$ & $\begin{array}{l}\text { Employment } \\
\text { share (WDI) }\end{array}$ \\
\hline \multicolumn{5}{|c|}{ Asian countries in sample } \\
\hline BGD & Bangladesh & 1959-2014 & 1960-2015 & $\begin{array}{l}1980,84-86, \\
89-91,95-96, \\
2000,02-03,05, \\
10\end{array}$ \\
\hline $\mathrm{CHN}$ & China* & $1952-2014$ & 1960-2015 & $1985,87-2011$ \\
\hline HKG & Hong Kong* & 1960-2014 & 2000-2014 & 1980-2008, 10 \\
\hline IDN & Indonesia* & 1960-2014 & 1960-2015 & $\begin{array}{l}\text { 1980, 82, } \\
85-2014\end{array}$ \\
\hline IND & India* & 1950-2014 & 1960-2014 & $\begin{array}{l}1990,94-95, \\
2000,05,10, \\
12-13\end{array}$ \\
\hline JPN & Japan* & 1950-2014 & 1970-2014 & $\begin{array}{l}\text { 1980-2010, } \\
12-13\end{array}$ \\
\hline KHM & Cambodia & 1970-2014 & 1993-2015 & $\begin{array}{l}1995,98, \\
2000-01,04-05, \\
08,10\end{array}$ \\
\hline KOR & South Korea* & 1953-2014 & $1965-2015$ & 1980-2013 \\
\hline LAO & Laos & 1970-2014 & 1989-2015 & $1995-2010$ \\
\hline LKA & Sri Lanka & 1950-2014 & 1960-2015 & $\begin{array}{l}1980-81,85, \\
90-98,2000, \\
02-14\end{array}$ \\
\hline MYS & Malaysia* & 1955-2014 & 1960-2015 & $\begin{array}{l}\text { 1980-93, } \\
\text { 95-2014 }\end{array}$ \\
\hline NPL & Nepal & 1960-2014 & $1965-2015$ & $\begin{array}{l}1990-91,95, \\
99-2001,05,08, \\
10,13\end{array}$ \\
\hline PAK & Pakistan & 1950-2014 & 1960-2015 & $\begin{array}{l}\text { 1980-2011, } \\
13-14\end{array}$ \\
\hline PHL & Philippines* & 1950-2014 & 1960-2015 & 1980-2014 \\
\hline SGP & Singapore* & 1960-2014 & 1975-2014 & 1980-2006, 10 \\
\hline THA & Thailand* & 1950-2014 & 1960-2014 & 1980-2013 \\
\hline VNM & Vietnam & 1970-2014 & $1985-2015$ & $\begin{array}{l}1995-2006,10, \\
12-13\end{array}$ \\
\hline \multicolumn{5}{|c|}{ Sub-Saharan African countries in sample } \\
\hline AGO & Angora & 1970-2014 & 1985-2001 & 1992 \\
\hline
\end{tabular}


Table 9.5 (continued)

\begin{tabular}{|c|c|c|c|c|}
\hline Code & Country & PWT & $\begin{array}{l}\text { Value added } \\
\text { share (WDI) }\end{array}$ & $\begin{array}{l}\text { Employment } \\
\text { share (WDI) }\end{array}$ \\
\hline BDI & Burundi & 1960-2014 & $1970-2015$ & 1998 \\
\hline BEN & Benin & 1959-2014 & 1960-2015 & 2003,10 \\
\hline BFA & Burkina Faso & 1959-2014 & $1960-2015$ & $\begin{array}{l}\text { 1994, 2003, } \\
05-07\end{array}$ \\
\hline BWA & Botswana* & 1960-2014 & $\begin{array}{l}\text { 1960-66, } \\
1975-2015\end{array}$ & $\begin{array}{l}1985,96,98, \\
2000-01,03,06, \\
10\end{array}$ \\
\hline CAF & $\begin{array}{l}\text { Central African } \\
\text { Republic }\end{array}$ & 1960-2014 & $1965-2015$ & N.A. \\
\hline CIV & Côte d'Ivoire & 1960-2014 & $1960-2015$ & N.A. \\
\hline CMR & Cameroon & 1960-2014 & $1965-2015$ & 1986,2001 \\
\hline COD & $\begin{array}{l}\text { D.R. of the } \\
\text { Congo }\end{array}$ & 1950-2014 & $1991-2015$ & N.A. \\
\hline $\mathrm{COG}$ & Congo & 1960-2014 & $1960-2015$ & 2005 \\
\hline $\mathrm{COM}$ & Comoros & 1960-2014 & 1980-2014 & N.A. \\
\hline $\mathrm{CPV}$ & Cabo Verde & 1960-2014 & 1980-2015 & N.A. \\
\hline ETH & Ethiopia* & $1950-2014$ & $1981-2015$ & $\begin{array}{l}\text { 1994, 2004-06, } \\
2011-13\end{array}$ \\
\hline GAB & Gabon & 1960-2014 & $2001-2015$ & 1993,2005 \\
\hline GHA & Ghana* & 1955-2014 & $1960-2015$ & $\begin{array}{l}1992,99,2006, \\
10,13\end{array}$ \\
\hline GIN & Guinea & 1959-2014 & $1986-2015$ & 1994, 2009-12 \\
\hline GMB & Gambia & 1960-2014 & 2004-2014 & 1993, 2014 \\
\hline GNB & Guinea-Bissau & 1960-2014 & 1970-2014 & N.A. \\
\hline GNQ & $\begin{array}{l}\text { Equatorial } \\
\text { Guinea }\end{array}$ & 1960-2014 & N.A. & 1983 \\
\hline KEN & Kenya* & 1950-2014 & 1960-2015 & 2005 \\
\hline LBR & Liberia & 1964-2014 & N.A. & 2007,10 \\
\hline LSO & Lesotho & 1960-2014 & 1960-2014 & $\begin{array}{l}1996-97,99, \\
2008\end{array}$ \\
\hline MDG & Madagascar & 1960-2014 & $1966-2015$ & $2003,05,12$ \\
\hline MLI & Mali & 1960-2014 & $1967-2015$ & 2004, 06 \\
\hline $\mathrm{MOZ}$ & Mozambique & 1960-2014 & 1980-2015 & 2003 \\
\hline MRT & Mauritania & 1960-2014 & 1960-2014 & N.A. \\
\hline MUS & Mauritius* & 1950-2014 & $1976-2015$ & $\begin{array}{l}1990,92, \\
94-2007, \\
2011-14\end{array}$ \\
\hline
\end{tabular}


Table 9.5 (continued)

\begin{tabular}{|c|c|c|c|c|}
\hline Code & Country & PWT & $\begin{array}{l}\text { Value added } \\
\text { share (WDI) }\end{array}$ & $\begin{array}{l}\text { Employment } \\
\text { share (WDI) }\end{array}$ \\
\hline MWI & Malawi* & 1954-2014 & 1960-2015 & 2013 \\
\hline NAM & Namibia & 1960-2014 & 1980-2015 & $\begin{array}{l}1991,97,2000, \\
04,08,10-13\end{array}$ \\
\hline NER & Niger & 1960-2014 & 1960-2015 & 2005 \\
\hline NGA & Nigeria* & 1950-2014 & $1981-2015$ & $\begin{array}{l}1983,86,2004, \\
07\end{array}$ \\
\hline RWA & Rwanda & 1960-2014 & $1965-2015$ & $1989,2005,12$ \\
\hline SDN & Sudan (former) & 1970-2014 & 1960-2015 & 2011 \\
\hline SEN & Senegal* & 1960-2014 & 1980-2015 & $2001,06,11$ \\
\hline SLE & Sierra Leone & 1961-2014 & 1964-2015 & 2003,04 \\
\hline STP & $\begin{array}{l}\text { Sao Tome and } \\
\text { principe }\end{array}$ & 1970-2014 & $2001-2014$ & $\begin{array}{l}\text { 1980-84, 91, } \\
2000,12\end{array}$ \\
\hline SWZ & Swaziland & 1970-2014 & 1960-2015 & N.A. \\
\hline SYC & Seychelles & 1960-2014 & 1976-2014 & 2011 \\
\hline TCD & Chad & 1960-2014 & 1960-2015 & 1993 \\
\hline TGO & Togo & 1960-2014 & 1960-2015 & 2006 \\
\hline TZA & $\begin{array}{l}\text { U.R. of } \\
\text { Tanzania* }\end{array}$ & 1960-2014 & 1990-2015 & $\begin{array}{l}\text { 1991, 2001, 02, } \\
06,07,14\end{array}$ \\
\hline UGA & Uganda & 1950-2014 & 1960-2015 & $\begin{array}{l}2002,03,05,09, \\
13\end{array}$ \\
\hline ZAF & South Africa* & $1950-2014$ & $1960-2015$ & $2000-14$ \\
\hline ZMB & Zambia* & 1955-2014 & $1965-2015$ & $\begin{array}{l}1990,98,2000 \\
05,08,12\end{array}$ \\
\hline ZWE & Zimbabwe & 1954-2014 & $1965-2015$ & $1999,2004,11$ \\
\hline \multicolumn{5}{|c|}{ North African countries excluded from sample } \\
\hline DZA & Algeria & 1960-2014 & $1965-2015$ & $2001,03,04,11$ \\
\hline EGY & Egypt & $1950-2014$ & $1965-2015$ & $\begin{array}{l}\text { 1980-84, } \\
1989-2013\end{array}$ \\
\hline TUN & Tunisia & 1960-2014 & 1965-2014 & $\begin{array}{l}1980-82,89, \\
2007-14\end{array}$ \\
\hline MAR & Morocco & $1950-2014$ & 1980-2014 & $\begin{array}{l}\text { 1990-93, } \\
1995-2012\end{array}$ \\
\hline
\end{tabular}

Note Countries indicated with * are included in GGDC data 


\section{References}

Aghion, P., Cai, J., Dewatripont, M., Du, L., Harrison, A., \& Legros, P. (2017). Industrial policy and competition. American Economic Journal: Macroeconomics, 7(4), 1-32.

Austin, G. (2014). Labour-intensity and manufacturing in West Africa, c.1450-c.2000. In G. Austin \& K. Sugihara (Eds.), Labour-intensive industrialization in global history (pp. 201-230). New York: Routledge.

Baldwin, R. E. (1969). The case against infant industry tariff protection. Journal of Political Economy, 77, 295-305.

Bloom, N., Genakos, C., Sadun, R., \& van Reenen, J. (2012). Management practices across firms and countries. Academy of Management Perspective, 26(1), 12-33.

Chang, H. J. (2007). Bad Samaritans: The myth of free trade and the secret history of capitalism. New York: Bloomsbury.

Criscuolo, C., Martin, R., Overman, H. G., \& van Reenen, J. (2012). The causal effects of an industrial policy. Working paper 17842, National Bureau of Economic Research.

De Vries, G., Timmer, M., \& De Vries, K. (2015). Structural transformation in Africa: Static gains, dynamic losses. Journal of Development Studies, 51, 674-688.

Diao, X., McMillan, M., \& Rodrik, D. (2017). The recent growth boom in developing economies: A structural change perspective. Working paper 23132, National Bureau of Economic Research.

Dinh, H. T., Palmade, V., Chandra, V., \& Cossar, F. (2012). Light manufacturing in Africa: Targeted policies to enhance private investment and create jobs. Washington, DC: World Bank.

Duarte, M., \& Restuccia, D. (2010). The role of the structural transformation in aggregate productivity. Quarterly Journal of Economics, 125, 129-173.

Easterly, W., \& Levine, R. (1997). Africa's growth tragedy: Policies and ethnic divisions. Quarterly Journal of Economics, 112, 1203-1250.

Estudillo, J. P., Cureg, E. F., \& Otsuka, K. (2018). Transformation of rural economies in Asia and Africa. In K. Otsuka \& K. Sugihara (Eds.) Paths to the Emerging State in Asia and Africa. (This Volume).

Fabricant, S. (1942). Employment in manufacturing, 1899-1939. National Bureau of Economic Research.

Feenstra, R. C., Inklaar, R., \& Timmer, M. P. (2015). The next generation of the Penn World Table. American Economic Review, 105, 3082-3150.

Frazer, G. (2008). Used-clothing donations and apparel production in Africa. Economic Journal, $118,1764-1784$.

Gollin, D., Lagakos, D., \& Waugh, M. E. (2014). The agricultural productivity gap. Quarterly Journal of Economics, 129, 939-993.

Goswami, A. G., Mattoo, A., \& Sáez, S. (2011). Exporting services: A developing country perspective. Washington, DC: World Bank.

Haraguchi, N., Cheng, C. F. C., \& Smeets, E. (2017). The importance of manufacturing in economic development: Has this changed? World Development, 93, 293-315.

Harrison, A., \& Rodríguez-Clare, A. (2010). Trade, foreign investment, and industrial policy for developing countries. In D. Rodrik \& M. R. Rosenzweig (Eds.), Handbook of development economics (Vol. 5, pp. 4039-4214). Amsterdam: Elsevier.

Hashino, T., \& Otsuka, K. (2016). Industrial districts in history and the developing world. Singapore: Springer.

Hausmann, R., Rodrik, D., \& Velasco, A. (2005). Growth diagnosis. Cambridge: Harvard University. Herrendorf, B., Rogerson, R., \& Valentinyi, A. (2014). Growth and structural transformation. In P. Aghion \& S. N. Durlauf (Eds.), Handbook of economic growth, Volume 2B. Amsterdam: Elsevier.

Higuchi, Y., Nam, V. H., \& Sonobe, T. (2015). Sustained impacts of kaizen training. Journal of Economic Behavior \& Organization, 120, 189-206.

Hino, H., \& Ranis, G. (2013). Youth and employment in Sub-Saharan Africa: Working but poor. Washington, DC: World Bank. 
Hirschman, A. O. (1958). The strategy of economic development. New Haven: Yale University Press.

Hsieh, C. T., \& Klenow, P. J. (2009). Misallocation and manufacturing TFP in China and India. Quarterly Journal of Economics, 124, 1403-1448.

Jensen, J. B. (2011). Global trade in services. Washington, DC: Peter G. Peterson Institute International Economics.

Krueger, A. O., \& Tuncer, B. (1982). An empirical test of the infant industry argument. American Economic Review, 72, 1142-1152.

Kubo, T. (2018). Changing patterns of industrialization and emerging states in twentieth century China. In K. Otsuka \& K. Sugihara (Eds.) Paths to the Emerging State in Asia and Africa. (This Volume).

Lal, D. (1983). The poverty of development economics. London: Institute of Economics Affairs.

Lane, N. (2017). Manufacturing revolutions: Industrial policy and networks in South Korea. Job Market Paper.

Lin, J. (2012). New structural economics: A framework for rethinking development and policy. Washington, DC: World Bank.

McKenzie, D., \& Woodruff, C. (2014). What are we learning from business training and entrepreneurship evaluations around the developing world? World Bank Research Observer, 29(1), 48-82.

McMillan, M., Rodrik, D., \& Verduzco-Gallo, I. (2014). Globalization, structural change, and productivity growth. World Development, 63, 11-32.

Mosley, P., Harrigan, J., \& Toye, J. (1995). Aid and power: The World Bank and policy-based lending, Volume 1: Analysis and policy proposals. New York: Routledge.

Newman, C., Page, J., Rand, J., Shimeles, A., Söderbom, M., \& Tarp, F. (2016). Made in Africa: Learning to compete in industry. Washington, DC: Brookings Institution Press.

Noman, A., \& Stiglitz, J. E. (2015). Industrial policy and economic transformation in Africa. New York: Columbia University Press.

Noman, A., \& Stiglitz, J. E. (2016). Efficiency, finance, and varieties of industrial policy: Guiding resources, learning, and technology for sustained growth. New York: Columbia University Press.

Nomura, C. (2018). Historical roots of industrialisation and the emerging state in Colonial India. In K. Otsuka \& K. Sugihara (Eds.) Paths to the Emerging State in Asia and Africa. (This volume).

Nurkse, R. (1953). Problems of capital formation in underdeveloped countries. Oxford: Oxford University Press.

Nunn, N., \& Trefler, D. (2010). The structure of tariffs and long-term growth. American Economic Journal: Macroeconomics, 2(4), 158-194.

Oqubay, A. (2015). Made in Africa: Industrial policy in Ethiopia. Oxford: Oxford University Press.

Overseas Economic Cooperation Fund (OECF, now JICA). (1993). Issues related to The World Bank's approach to structural adjustment: Proposals from a major partner. Occasional Paper No. 1, OECF.

Otsuka, K., Higuchi, Y., \& Sonobe, T. (2017a). Middle-income traps in East Asia: An inquiry into causes for slowdown in income growth. China Economic Review, 46, s3-1s16.

Otsuka, K., Mieno, F., Sonobe, T., Kurosaki, T., Shimada, G., Kitano, N., et al. (2017b). Traininginfrastructure-finance (TIF) strategy for industrial development in Sub-Saharan Africa. Tokyo, Japan: International Cooperation Agency (JICA) Research Institute.

Page, J. (2012). Can Africa industrialise? Journal of African Economies, 21, 86-124.

Reinert, E. S. (2007). How rich countries got rich and why poor countries stay poor. London: Constable.

Rodrik, D. (2010). The return of industrial policy. Project Syndicate, 12.

Rodrik, D. (2013). Unconditional convergence in manufacturing. Quarterly Journal of Economics, $128,165-204$.

Rodrik, D. (2016). Premature deindustrialization. Journal of Economic Growth, 21, 1-33.

Rosenstein-Rodan, P. N. (1943). Problems of industrialisation of Eastern and South-Eastern Europe. Economic Journal, 53, 202-211. 
Shimada, G., Homma, T., \& Murakami, H. (2013). Industrial development of Africa. In Japan International Cooperation Agency (Ed.), For inclusive and dynamic development in Sub-Saharan Africa. Tokyo: JICA Research Institute.

Shimada, G., \& Sonobe, T. (2017). Impacts of Kaizen management on workers: Evidence from the Central America and Caribbean Region. Working Paper. Tokyo: JICA Research Institute.

Sonobe, T., \& Otsuka, K. (2011). Cluster-based industrial development: A comparative study of Asia and Africa. New York: Palgrave Macmillan.

Stiglitz, J. E., Lin, J. Y., \& Patel, E. (2013). The industrial policy revolution II: Africa in the twenty-first century. New York: Palgrave Macmillan.

Stiglitz, J. E., \& Uy, M. (1996). Financial markets, public policy and the East Asian miracle. World Bank Research Observer, 11, 249-276.

Tanimoto, M. (2018). Labour-intensive industrialization and the emerging state in pre-war Japan. In K. Otsuka \& K. Sugihara (Eds.) Paths to the Emerging State in Asia and Africa. (This Volume).

Timmer, M. P., De Vries, G. J., \& De Vries, K. (2014). Patterns of structural change in developing countries. GGDC Research Memorandum 149.

Wade, R. (1990). Governing the market: Economic theory and the role of government in East Asian industrialization. Princeton: Princeton University Press.

Wade, R. (1996). Japan, The World Bank, and the art of paradigm maintenance: The East Asian miracle in political perspective. New Left Review (May-June).

World Bank. (2012). World development report 2013: Jobs. Washington, DC: World Bank.

Open Access This chapter is licensed under the terms of the Creative Commons AttributionNonCommercial-NoDerivatives 4.0 International License (http://creativecommons.org/licenses/bync-nd/4.0/), which permits any noncommercial use, sharing, distribution and reproduction in any medium or format, as long as you give appropriate credit to the original author(s) and the source, provide a link to the Creative Commons licence and indicate if you modified the licensed material. You do not have permission under this licence to share adapted material derived from this chapter or parts of it.

The images or other third party material in this chapter are included in the chapter's Creative Commons licence, unless indicated otherwise in a credit line to the material. If material is not included in the chapter's Creative Commons licence and your intended use is not permitted by statutory regulation or exceeds the permitted use, you will need to obtain permission directly from the copyright holder.

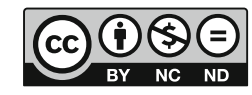

